\title{
PEMBERDAYAAN UKM BATIK SENG DESA SENGGURUH KABUPATEN MALANG
}

\author{
Boge Triatmanto ${ }^{1}$, Anwar Sanusi ${ }^{2}$, Aris Siswati ${ }^{3}$ \\ ${ }^{123}$ Universitas Merdeka Malang \\ Email: boge.triatmanto@unmer.ac.id
}

\begin{abstract}
Batik is one of the original types of Indonesian culture, even UNESCO has determined Batik as one of the world's cultural heritages. In its development came a variety of batik motifs including the ways or processes used in producing batik. Indonesia recognizes batik as a form of art work done by humans by giving certain patterns to plain cloth by waxing wax to block color, which is what is known as batik cloth. The making of written batik requires special expertise because the process must be carried out through certain stages. The quality of the finished batik cloth is very dependent on the skills of batik craftsmen to go through each stage of the batik process. Sengguruh Village, Malang Regency has a Batik Written UKM which has quite potential to develop its business. But the lack of the number of crafters possessed is an obstacle in producing written batik. Another obstacle experienced is the lack of understanding of written batik craftsmen to each stage of the process that must be passed. The results of the handmade batik SOP training provide new knowledge and provide deeper understanding to the batik crafters, so that when the batik process is passed well it will produce batik cloth which is also better in quality.
\end{abstract}

Keywords: Batik, Sengguruh Village.

\section{PENDAHULUAN}

Analisis Situasi

Kepanjen adalah salah satu Kecamatan dari 33 Kecamatan yang ada di Kabupaten Malang. Kecamatan Pagelaran terdiri dari 4 Kelurahan (Ardirejo, Cempokomulyo, Penarukan, Kepanjen) dan 14 Desa (Curungrejo, Dilem, Jatirejoyoso, Jenggolo, Kedung Pedaringan, Kemiri, Mangunrejo, Mojosari, Ngadilangkung, Panggungrejo, Sengguruh, Sukoharjo, Tegalsari, Tulungagung). Kepanjen memiliki luas wilayah 44,68 $\mathrm{Km}^{2}$, berada pada ketinggian 350 Meter Di atas Permukaan Laut. Terletak $20 \mathrm{Km}$ dari Kota Malang, Kecamatan dilintasi oleh jalur utama transportasi Surabaya-Malang-Blitar. Jalur rel ini juga menghubungkan dengan kota-kota lain di Pulau Jawa seperti Surabaya-MalangBlitar-Jakarta dan kota lainnya, didukung dengan adanya Stasiun Kepanjen dan Terminal Kepanjen. Secara topografi wilayahnya berada di daerah dataran rendah. Sehingga sebagian besar penduduknya bermatapencarian sebagai petani, dan beberapa profesi penduduk yang lain adalah pedagang, industri pengolahan dan sebagai karyawan di beberapa usaha industri yang lain.

Lokasi mitra berada tepatnya di Desa Sengguruh yang merupakan salah satu Desa yang masuk wilayah Kecamatan Kepanjen, letaknya paling ujung selatan dari Kecamatan Pagak dan berbatasan langsung dengan Kecamatan Pagak. Luas wilayahnya sekitar 116 Ha, dengan ketinggian 135 Meter di atas permukaan laut dan suhu rata-rata berkisar 25$30^{\circ}$ Celcius. Topografi Desa Sengguruh sebagian besar berupa dataran, meskipun bagian selatan Desa berbatasan dengan gunung kapur dan sungai Brantas, namun tidak terdapat pegunungan/perbukitan. 
Kerajinan batik merupakan salah satu jenis kerajinan asli bangsa Indonesia yang sudah sangat terkenal dengan keindahan motifnya dan juga sarat dengan berbagai nilai filosofi. Badan khusus PBB yaitu UNESCO bahkan telah mencanangkan Batik sebagai warisan budaya dunia, tepatnya pada 2 Oktober 2009. Keberadaan Batik Indonesia semakin mendunia, hal ini tentu saja berdampak pada apresiasi masyarakat Indonesia sendiri bahkan oleh masyarakat dunia dengan semakin meningkatnya permintaan produk Batik terutama kain batik. Pangsa pasar batik juga semakin meluas, tidak hanya untuk kebutuhan permintaan dalam negeri, bahkan produksi batik sudah merambah pasar luar negeri. Hal ini tentu saja membuka peluang baru bagi masyarakat untuk selain mengembangkan ide kreatif dalam desain batik, namun juga untuk meningkatkan kegiatan perekonomian masyarakat.

Beragam segmen pasar yang menjadi sasaran para pengusaha batik tentu saja menentukan kuantitas maupun kualitas batik yang dihasilkan. Untuk kebutuhan segmen pasar konsumen menengah keatas dan pasar luar negeri tentu saja kualitas produk menjadi syarat utama dalam produk yang dihasilkan. Kualitas produk yang dihasilkan akan sangat bergantung kepada keterampilan para perajin batik dalam memproduksi batik.

Pemberlakuan ACFTA tahun 2010 dan MEA tahun 2015 menjadi tantangan tersendiri bagi para pengusaha Batik di Indonesia karena bahwa ternyata Indonesia bukanlah satu-satunya negara yang memproduksi batik (Baidawi, Rahayu, \& Harmadji, 2017). Beberapa negara Asia lainnya yaitu Malaysia, China, Vietnam dan Thailand merupakan negara-negara yang juga mengembangkan dan memproduksi batik. Sehingga ketika berada di pasar, harga produk sangat mempengaruhi keputusan beli konsumen. Kondisi tersebut menuntut para pengusaha batik Indonesia untuk dapat menghasilkan produk batik yang nantinya akan diminati oleh konsumen. Indonesia masih mempunyai peluang yang cukup besar dalam memenangkan hati konsumen dengan mengkhususkan produknya pada Batik Tulis. Corak dan motif batik tulis sangat berbeda dengan batik tulis cap maupun print, dan hal inilah yang menjadi keistimewaan pada batik tulis.

Pengusaha batik tulis yang dalam hal ini biasanya juga sebagai perajin seringkali dihadapkan pada beberapa kendala dalam usahanya. Diantaranya adalah biaya produksi yang cukup tinggi sehingga berimbas pada harga jual batik tulis yang pada akhirnya akan cukup mahal. Tidak banyak konsumen yang memahami mengapa harga jual batik tulis cukup tinggi, sehingga pangsa pasar batik tulis juga terbatas.

Salah satu pengusaha batik tulis yang ada di Desa Sengguruh, UKM Batik Seng merupakan salah satu UKM yang secara kualitas produknyadapat dinilai cukup bagus. Hal ini terbukti dengan banyaknya pesanan batik tulis yang diterima yaitu sekitar 100 lembar setiap bulannya. UKM Batik Seng cukup berpengalaman dalam menghasilkan berbagai corak dan motif batik tulis. Kegiatan usaha yang dilakukan tidak sebatas memproduksi saja, namun juga aktif dalam mengenalkan produknya melalui berbagai kegiatan pameran dan mensosialisasikan proses pembuatan batik baik kepada masyarakat sekitar yang lain maupun kepada kalangan terpelajar dalam hal ini adalah siswa-siswi Sekolah Dasar. Ada tujuan jangka panjang yang diinginkan UKM Batik Seng, bahwa Batik tulis khususnya harus menjadi salah satu budaya yang melekat pada semua generasi di Indonesia. Untuk itu maka perlu adanya pengenalan sedari dini mengenai budaya batik tulis ini, sehingga generasi muda tidak akan lupa dengan identitas budaya bangsanya mengingat semakin waktu gempuran masuknya budaya asing juga cukup kuat. 


\section{Permasalahan}

Tim PPMUPT telah berkordinasi dengan mitra dan tokoh masyarakat Desa Sengguruh terkait identifikasi kendala dan permasalahan yang dihadapi oleh UKM Batik Seng. Dari hasil pertemuan tersebut telah diidentifikasi beberapa persoalan yang salah satu diantaranya adalah bahwa dalam proses produksi (SOP) batik tulis belum semua pengrajin memahami tentang standar operasional prosedur pembuatan batik tulis. Sehingga dalam produksi akan terjadi beberapa kesalahan yang sebenarnya hal itu bisa diminamilisir apabila perajin memahami dan melaksanakan SOP batik tulis.

\section{Kondisi saat ini dan permasalahan prioritas yang disepakati}

UKM Batik Seng memiliki kurang lebih 15 orang perajin, dan dari ke 15 orang perajin tersebut masing-masing orang mempunyai spesifikasi pekerjaan dalam proses produksi batik. Spesifikasi tersebut adalah sebagai desainer motif, pencanting, dan pewarna. Pengelola batik pada dasarnya tidak melakukan pembagian kerja secara khusus, namun seiring berjalannya waktu para perajin menentukan sendiri bagian kerjanya sesuai dengan keterampilan yang dimilikinya. Setelah dilakukan penelusuran oleh tim, hal tersebut ternyata disebabkan karena para perajin belum mengetahui bahwasanya dalam proses produksi batik tulis sebenarnya ada tahapan baku atau disebut juga SOP batik tulis yang sebenarnya harus dilalui dengan harapan supaya produksi menjadi lebih efektif dan efisien. Hal ini juga didukung oleh fakta bahwa belum tersedianya beberapa peralatan standart yang seharusnya dimiliki oleh usaha batik tulis, diantaranya adalah gawangan dan bak pewarna.

\section{Metode Pelaksanaan}

Penyelesaian permasalahan dilakukan dengan 2 tahap kegiatan yaitu: pertama penyusunan dan pelatihan SOP batik tulis, kedua adalah pelatihan praktik produksi batik tulis sesuai SOP batik tulis. Pada tahap penyusunan dan pelatihan SOP batik tulis, disusun SOP batik tulis sekaligus mengurai setiap tahapannya. Selain diurai setiap tahapan proses membuat batik tulis, para perajin juga mendapatkan keterangan manfaat dari setiap tahapan proses tersebut.

Tahap yang kedua yaitu praktik untuk membuat batik tulis sesuai dengan SOP batik yang telah disusun sebelumnya. Bahwa selama ini proses produksi berjalan dan telah menghasilkan banyak kain batik tulis oleh para perajin batik tulis, namun ternyata tidak semua proses yang dilakukan oleh perajin sesuai dengan SOP. Banyak dari perajin tidak memahami makna dari setiap proses yang sebenarnya harus dilakukan. Hal tersebut tentu saja berkaitan dengan keefektifan dan efisiensi produksi. Pelaksanaan praktik proses produksi batik tulis sesuai dengan SOP dilaksanakan dengan menggunakan alat dan bahan yang standart.

\section{Hasil Kegiatan \\ Penyusunan SOP Batik Tulis}

Membatik adalah kegiatan memberi motif pada kain polos dengan metode merintangi pewarna dengan menggunakan malam/lilin. Pada awal perkembangannya di Indonesia metode tersebut dilakukan dengan teknik tulisan tangan menggunakan alat bahan canting dan malam. Perkembangan selanjutnya menghasilkan inovasi baru yaitu menggunakan cap atau yang dikenal dengan batik cetak, dan pada era baru ini bahkan batik dapat diproduksi dengan teknik otomatisasi yang disebut dengan batik print. SOP (Standart Operasional Prosedur) batik tulis adalah dokumen yang berkaitan dengan 
prosedur yang dilakukan secara kronologis untuk menyelesaikan suatu pekerjaan yang bertujuan untuk memperoleh hasil kerja yang paling efektif dari para pekerja dengan biaya seefisien mungkin.

Perbedaan teknik pembuatan batik tentu saja akan menghasilkan motif yang saling berbeda, dan hal inilah yang sangat membedakan diantaranya yaitu pada batik tulis. Proses produksi batik tulis sangat bergantung pada keterampilan perajin batik dalam mencanting dan mewarna. Disamping itu waktu yang diperlukan dalam proses pembuatan batik tulis juga terbilang cukup lama terutama untuk motif tertentu yang cukup rumit sehingga hal ini berpengaruh terhadap harga jual batik tulis itu sendiri (Muhammad Baidawi; Yayuk Ngesti Rahayu; Dwi Ekasari H., 2018).

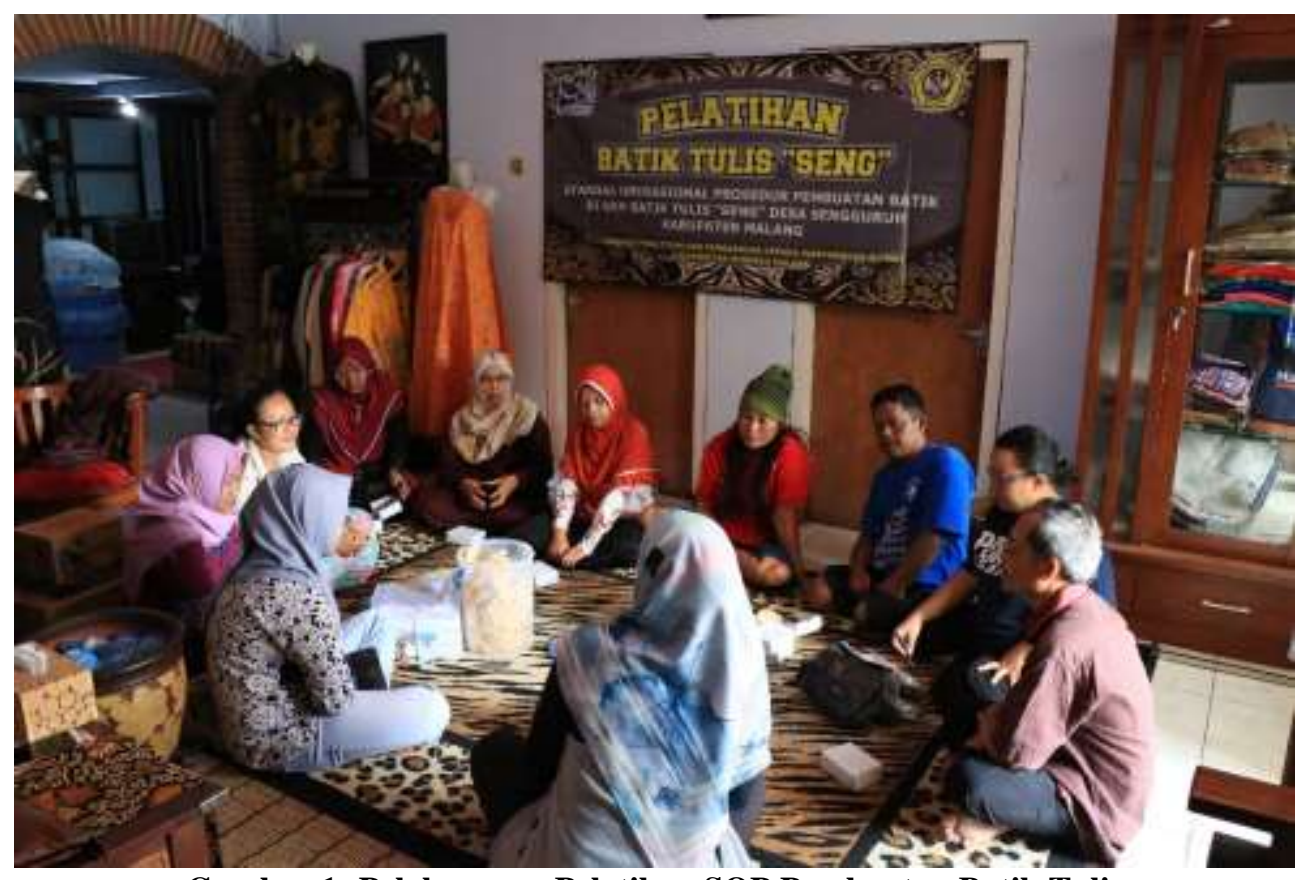

Gambar 1: Pelaksanaan Pelatihan SOP Pembuatan Batik Tulis

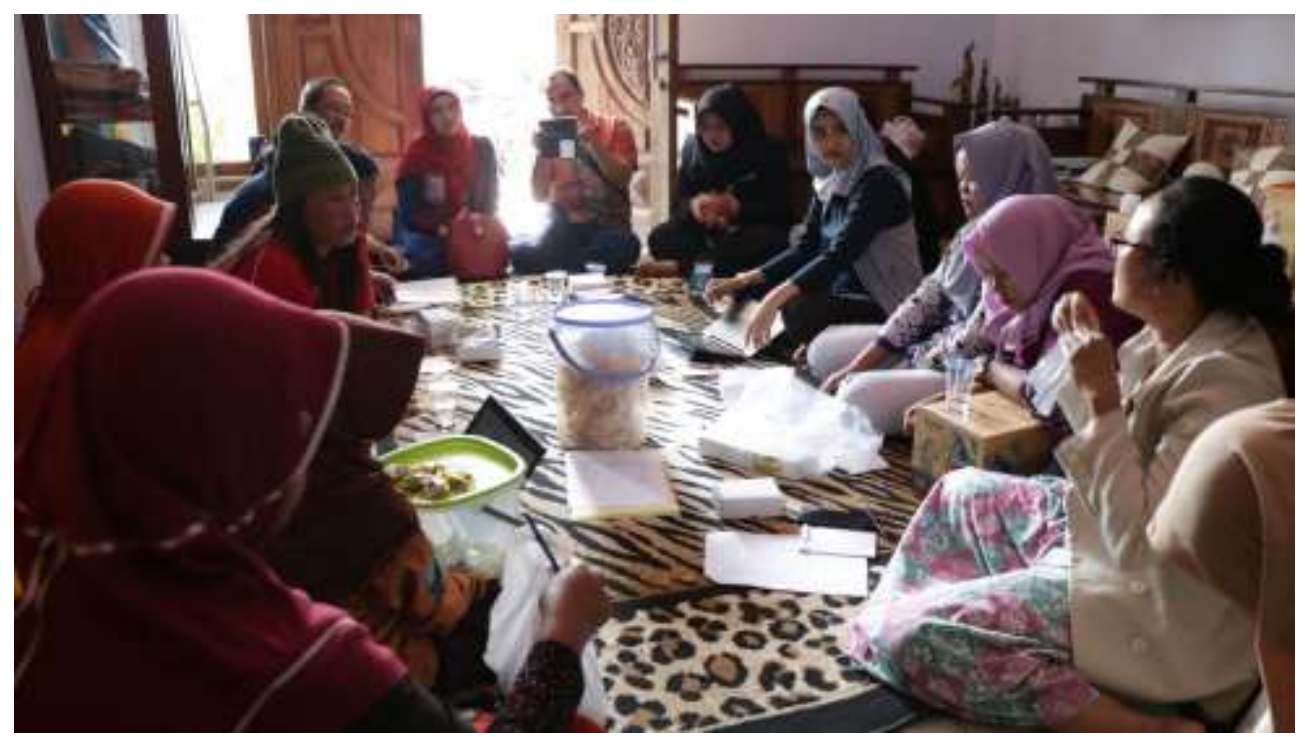

Gambar 2: Narasumber Menyampaikan Materi 
Proses produksi batik tulis terdiri dari 2 tahap utama yaitu: pertama mencanting (dilakukan secara manual oleh perajin dengan menggunakan alat bantu canting dan bahan berupa malam) dan yang kedua adalah mewarna (yang dapat dilakukan dengan menggunakan pewarna alami maupun pewarna sintesis). Sesuai dengan SOP yang telah disusun, berikut adalah tahapan proses pembuatan batik tulis:

1. Niat

Niat dimasukkan dalam dokumen SOP batik tulis, karena hal ini berhubungan dengan komitmen seseorang dalam melaksanakan proses pembuatan batik. Batik yang dapat digolongkan menjadi produk seni dalam hasil produksi nantinya akan sangat bergantung dengan kreatifitas perajin. Seorang perajin batik yang mengerjakan pembuatan batik tulis dengan penuh keniatan dapat dipastikan hasil goresan tangannya akan menjadi indah. Kesabaran juga merupakan hal yang dituntut dari seorang perajin batik tulis, karena proses yang dilakukan dalam menghasilkan sebuah karya kain batik tulis juga harus melewati beberapa tahapan.

2. Mempersiapkan alat dan bahan

Sebelum memulai proses membatik, semua alat dan bahan harus dipersiapkan terlebih dahulu. Hal ini untuk mengefektifkan waktu yang akan kita gunakan dan selain itu apabila alat dan bahan telah tersedia maka proses membatik akan lebih mudah dilakukan karena perajin akan dapat lebih fokus pada tahapan atau teknik pengerjaan. Berikut adalah alat dan bahan yang harus dipersiapkan untuk membuat batik tulis.

Alat yang dipergunakan dalam membatik:

1) Kertas, digunakan untuk membuat pola batik yang apabila sudah menjadi sebuah gambar maka akan diaplikasikan di kain.

2) Pensil, digunakan untuk menggambar di kain sesuai pola yang sudah dibuat di kertas.

3) Karbon, digunakan untuk menggambar duplikat pola dari pola yang sudah digambar di kertas.

4) Penggaris, digunakan apabila memerlukan gambar garis pada kain (biasanya apabila batik memerlukan pola pinggiran pada tepi kain).

5) Penghapus, digunakan untuk menghapus goresan pensil pada kain.

6) Meja biasa dan meja kaca, digunakan untuk menggambar pola batik baik dikertas maupun di kain bahan yang akan dibatik.

7) Gawangan, digunakan untuk merentangkan kain yang akan dicanting sehingga hasil cantingan tidak pecah dan malam yang tertempel di kain cepat kering.

8) Wajan atau kompor malam, digunakan untuk memanaskan malam supaya malam mencair sehingga dapat diplikasikan ke kain.

9) Anting, digunakan untuk membuat goresan malam pada kain. Canting terdiri dari berbagai jenis ukuran tergantung dari ketebalan garis yang diperlukan digoreskan di kain.

10) Goni, digunakan sebagai alas pekerjaan mencanting, hal ini berfungsi supaya apabila terdapat malam yang menetes tidak langsung mengotori lantai sehingga lebih mudah untuk dibersihkan.

11) Kuas kecil, digunakan pada saat pewarnaan dengan teknik remasol, yaitu dengan cara menggoreskan kuas yang telah dicelup di cairan pewarna ke bagian kain yang ingin diberikan warna tertentu.

12) Bak celup warna/kerekan, digunakan pada saat pewarnaan dengan teknik naptol, yaitu mencelup kain pada pewarna yang telah ditampung di bak pewarna.

13) Kompor besar, digunakan sebagai alat sumber pemanas untuk memanaskan air dalam panic. 
14) Panci lorod, digunakan sebagai alat penampung air yang nantinya akan dipanaskan dan merebus kain untuk menghilangkan malam pada kain.

Bahan yang diperlukan dalam membatik:

1) Kain berbahan alam (katun, sutra)

2) Malam batik

3) Pewarna, dapat berupa pewarna alami (dari daun-daunan, kulit kayu, bunga)

Seluruh alat dan bahan tersebut harus dalam kondisi siap untuk digunakan, baik dari segi fungsi maupun jumlah yang diperlukan. Oleh karena itu sangat penting juga bahwa apabila alat telah selesai dipergunakan maka harus dibersihkan dan disimpan secara rapi, supaya alat tersebut kembali siap digunakan apabila melakukan proses membatik lagi. Hal ini merupakan salah satu bentuk perawatan terhadap alat sehingga masa pakai alat juga lebih lama dan resiko timbulnya kerusakan alat karena kelalaian pengguna dapat diminimalisir dan berimbas pada efisiensi biaya yang dikeluarkan. Mempersiapkan bahan bermanfaat juga untuk memperhitungkan jumlah bahan yang diperlukan sehingga tidak ada bahan yang terbuang sia-sia dalam proses produksi.

3. Ngemplong/ngeteli/mordan

Ngemplong/ngeteli/mordan artinya memberikan perlakuan khusus pada kain sebelum kain melalui proses pembatikan. Hal ini bertujuan untuk memurnikan kain, agar sisa-sisa bahan kimia yang mungkin terkandung di kain dapat hilang. Manfaat dari proses ini adalah kain dapat menerima malam yang dicanting dengan mudah, selain itu ketika melalui proses pewarnaan akan menghasilkan warna sesuai dengan yang diinginkan karena kain sudah tidak mengandung bahan kimia lain.

Teknik yang dilakukan adalah dengan cara perendaman dan atau merebus kain dengan air tawas kemudian kain dicuci bilas berulang. Cara lain yang dapat dilakukan adalah dengan melemaskan kain dengan merebus kain bersama merang bakar atau memberikan minyak kacang baru kemudian dilakukan cuci bilas berulang.

4. Mola

Membuat gambar tertentu pada kertas yang disesuaikan dengan panjang dan lebar kain yang akan dijadikan batik tulis dengan menggunakan aturan tertentu. Untuk membuat pola perlu dipertimbangkan bagaimana pertemuan gambar nantinya pada kain, itulah mengapa ada teknik khusus dalam membuat pola dikertas.

5. Nyoret/nyungging

Nyoret/nyungging adalah menyalin gambar sesuai dengan pola dikertas yang sudah dibuat pada kain. Alat bantu yang digunakan adalah pensil dan kertas karbon (apabila diperlukan motif yang sama pada beberapa lembar kain). 

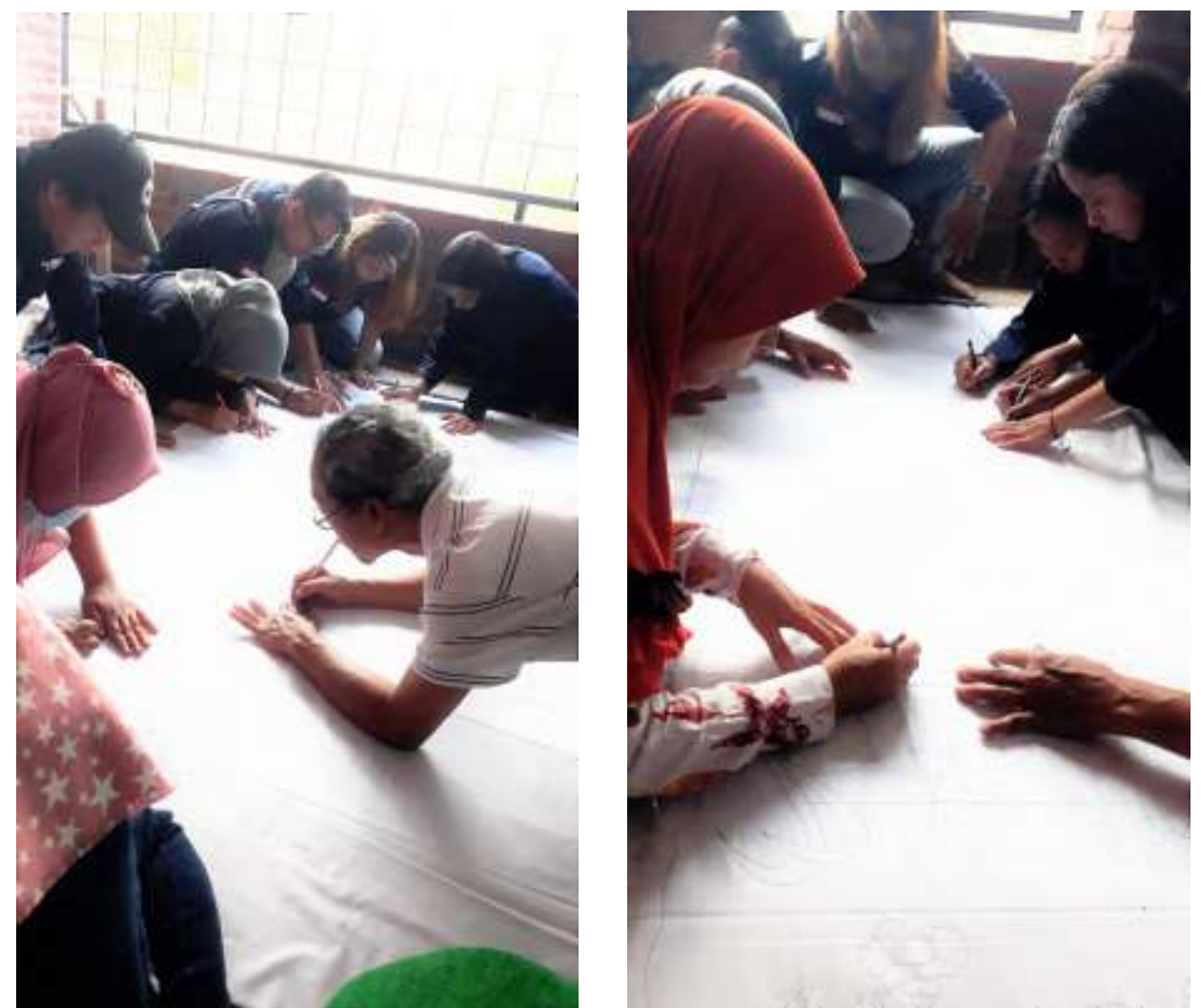

Gambar3. Menggambar Pola Pada Kain Mori

\section{Nyanting}

Mencanting atau nyanting adalah kegiatan menggoreskan alat canting yang sudah terisi malam pada kain yang akan dijadikan batik tulis. Proses mencanting ada empat jenis, yaitu:

(1) Nglowong, adalah proses pencantingan pertaman untuk garis luar gambar dengan menggunakan jenis canting klowong yang berukuran besar.

(2) Ngiseni, adalah mencanting dengan maksud untuk memberi isian (isen-isen) berupa goresan yang lebih kecil didalam gambar besar yang sudah diklowong, canting yang digunakan adalah jenis yang berukuran kecil yaitu 1 atau 0,5.

(3) Mbliriki/nerusi, adalah mencanting kembali gambar yang sudah diklowong dari sisi balik kain, supaya hasilnya lebih bagus. Hal ini juga berguna apabila ternyata pada hasil cantingan klowong, malam tidak meresap menembus balik kain. Apabila malam tidak menembus balik kain maka pada proses pewarnaan nantinya warna yang sebenarnya diharapkan berada dibagian tertentu akan menyebar ke bagian lain. Sehingga sesuai dengan definisi batik tulis diatas bahwa membatik adalah proses membatasi warna pada kain dengan malam. 


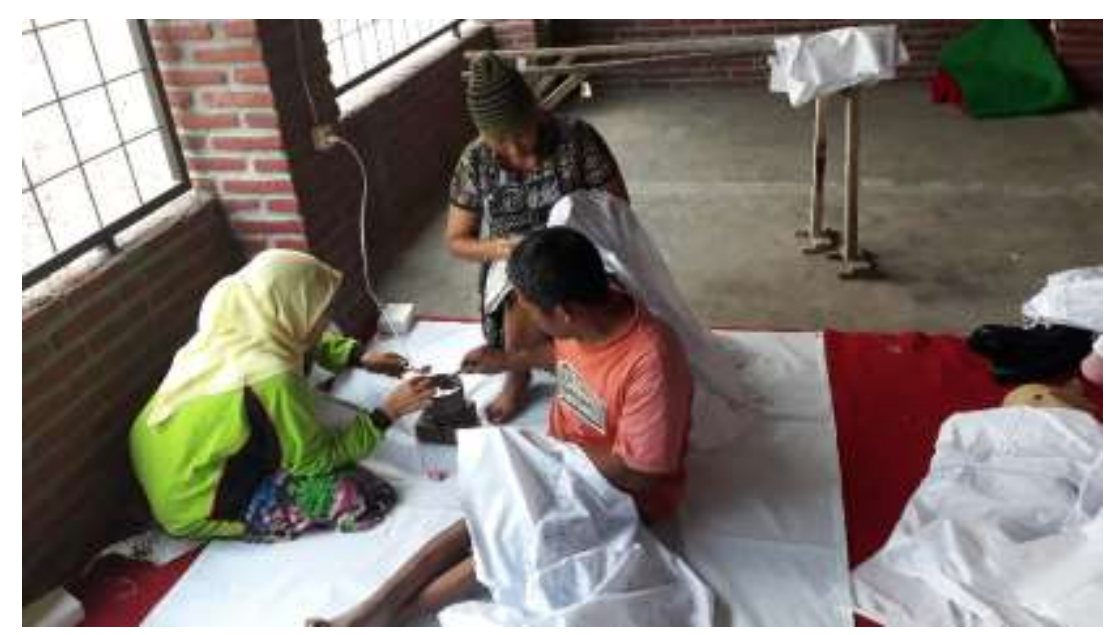

Gambar 4: Proses Mencanting

(4) Mopok/nembok, adalah proses melekatkan malam pada kain yang sudah diwarna secara menyeluruh. Hal ini biasanya dilakukan pada kain yang sudah dicolet, pada produksi batik tulis dengan teknik pewarnaan naptol.

7. Nyolet

Nyolet atau menyolet artinya adalah memberi warna pada bagian tertentu gambar untuk mendapatkan hasil efek tertentu. Alat bantu yang digunakan adalah kuas dan tentu saja bahannya adalah pewarna kain. Diperlukan kesabaran dan ketelitian dalam proses nyolet ini karena perajin harus memahami betul desain gambarnya sehingga nyolet yang dilakukan tepat pada bagian tertentu, dan sangat sukar untuk mengkoreksi kesalahan nyolet pada bagian yang tidak tepat.

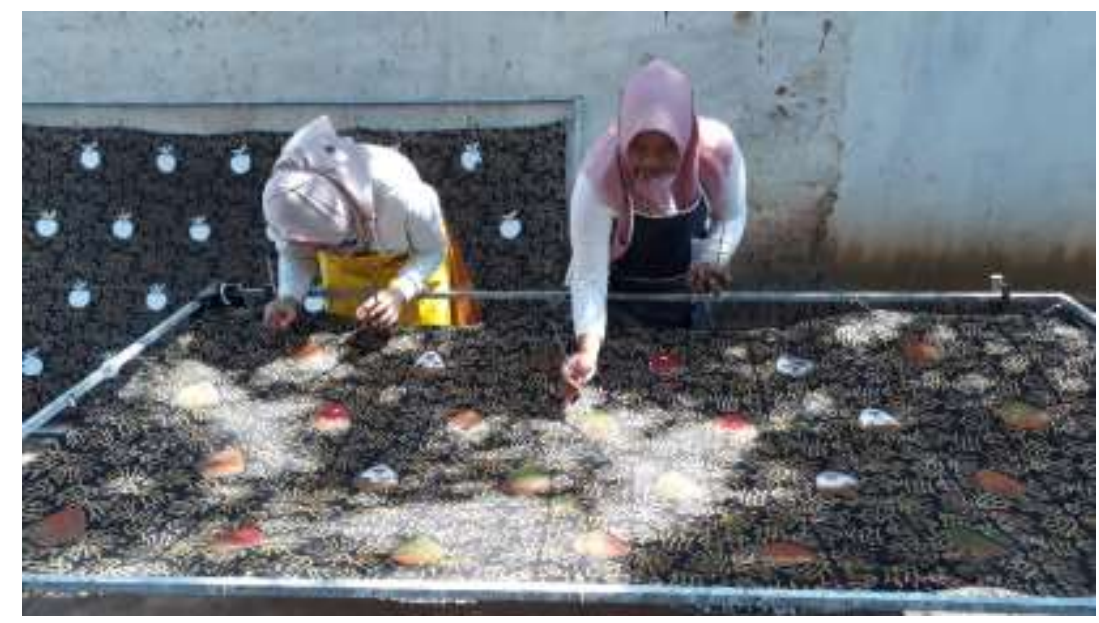

Gambar 5: Proses Nyolet 


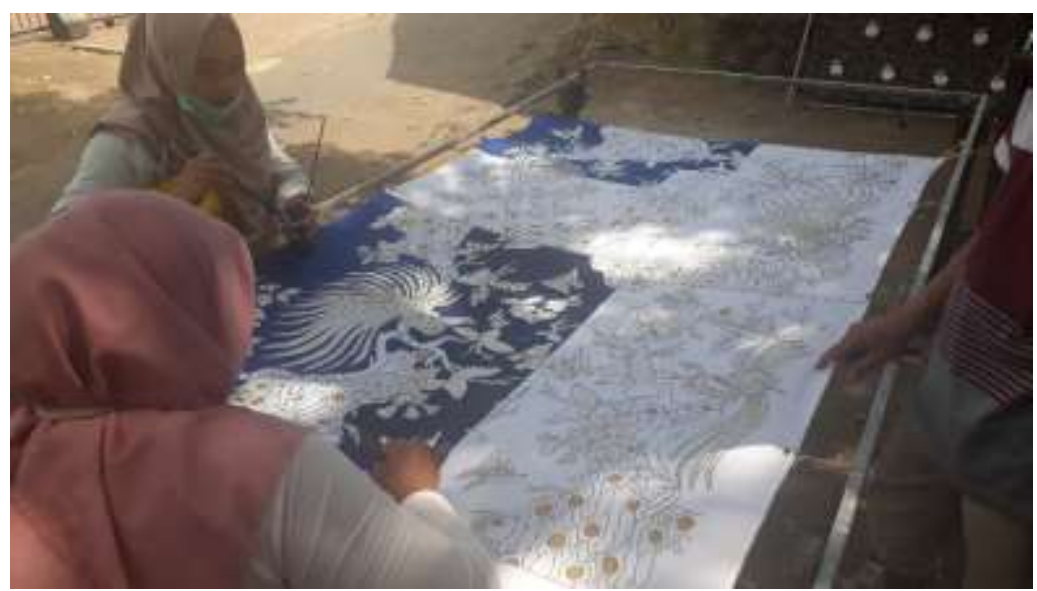

Gambar 6. Menyolet

\section{Ngelir}

Ngelir adalah proses pemberian warna secara menyeluruh pada kain dengan cara dicelup melalui 3 tahapan, yaitu:

(1) Model, adalah pemberian warna pertama pada kain dengan cara dicelup, yang fungsinya adalah untuk memberi pola luar bentuk gambar. Pada awalnya dulu warna yang digunakan adalah warna biru tua, namun sekarang saat ini dapat menggunakan warna apa saja.

(2) Nyoga, adalah pewarnaan kedua yang akan menghasilkan warna coklat. Hal ini tergantung atas hasil yang diinginkan sehingga komposisi pewarna juga menyesuaikan.

(3) Mbironi, adalah pewarnaan yang terakhir dengan maksud untuk mempertegas dengan memberi warna gelap.

9. Nglorod

Nglorod adalah proses menghilangkan malam yang menempel pada kain, dengan cara merebus kain di air mendidih. Pada proses ini, motif dan corak batik yang telah dibuat akan dapat terlihat hasilnya. Setelah seluruh malam sudah luruh pada air maka dilanjutkan dengan proses pengeringan kain dengan cara diangin-anginkan.

10. Pengemasan

Sebagai barang yang akan menjadi komoditi jual, kain batik tulis yang sudah jadi memerlukan proses pengemasan. Pengemasan ini berfungsi selain untuk melindungi kain batik tulis, juga untuk meningkatkan penampilan kain batik tulis sehingga akan terlihat lebih menarik bagi konsumen.

Perbandingan hasil produksi.

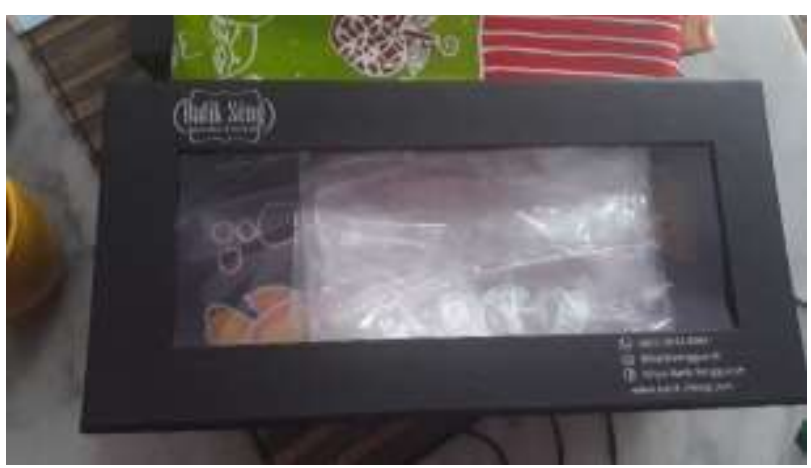

Gambar 7. Kemasan Batik Dalam Box 


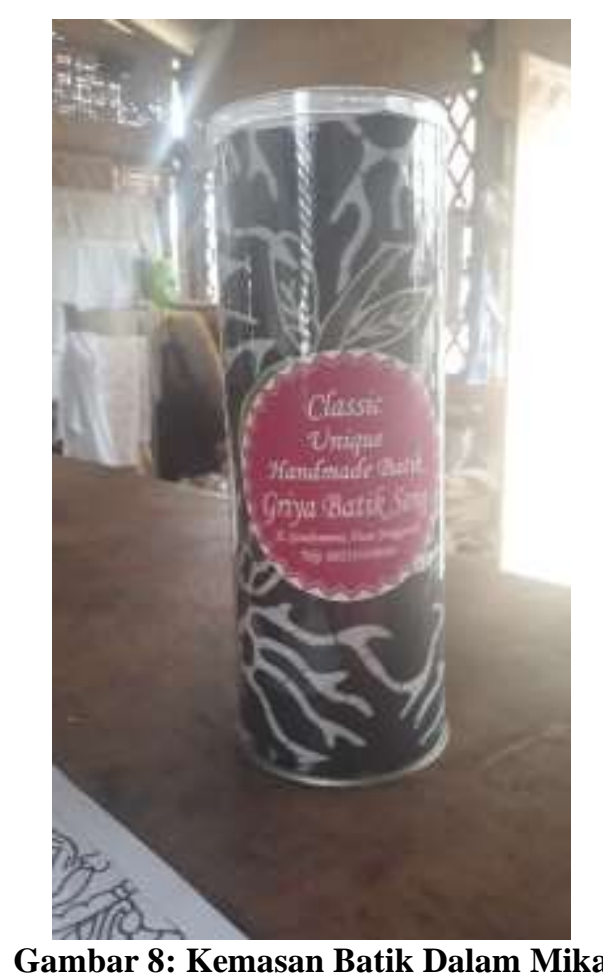

\section{Kesimpulan}

Hasil dari kegiatan pengabdian ini adalah menanamkan pemahaman kepada para perajin batik tulis bahwa terdapat SOP dalam proses produksi batik tulis. Kegiatan yang dilakukan selama ini oleh perajin merupakan bagian dari tahapan atau proses dalam SOP batik tulis. Tanpa disadari oleh perajin bahwa ternyata proses produksi batik tulis apabila dilaksanakan sesuai SOP maka akan meringankan beban kerja mereka, karena semua proses dapat direncanakan baik waktu maupun biaya yang akan dikeluarkan. Beberapa kendala yang selama ini dialami oleh perajin juga merupakan salah satu efek yang disebabkan oleh proses yang dilakukan tidak sesuai dengan SOP proses produksi batik tulis. Manfaat lain yang dirasakan pengusaha batik dengan menerapkan SOP batik tulis ini selain kemanfaatan secara biaya dan waktu adalah para perajin dapat belajar untuk melaksanakan proses lain yang selama ini tidak pernah mereka lakukan, sehingga masingmasing perajin akan mempunyai pengalaman dalam memproduksi batik tulis secara keseluruhan dan diharapkan dalam masa mendatang mereka dapat juga menjadi pengusaha batik secara mandiri.

\section{DAFTAR PUSTAKA}

Adi Prasetyo, Singgih, Karakteristik Motif Batik Kendal Interpretasi dari Wilayah dan Letak Geografis, Jurnal Imajinasi, Vol.X No.1, Januari 2016

Agus Suprapto, 2016, Sentra Kulakan Solusi Permasalahan UMKM dan Masyarakat Miskin, jurnal Abdimas Unmer Malang, ISSN 2548-7159 vol 1 no 1 Des 2016 
Baidawi, M., Rahayu, Y. N., \& Harmadji, D. E. (2017). Pengembangan Produk Ekspor Batik Podhek Di Kabupaten Pamekasan Provinsi Jawa Timur, 2(2).

Muhammad Baidawi; Yayuk Ngesti Rahayu; Dwi Ekasari H. (2018). PPPUD Industri Batik Podhek Di Kabupaten Pamekasan Provinsi Jawa Timur| PEDULI: Jurnal Ilmiah Pengabdian Pada Masyarakat. Retrieved October 19, 2019, from http://peduli.wisnuwardhana.ac.id/index.php/peduli/article/view/84

Hadi, Solichul, 2014, Sejarah dan Teknik Pembuatan Batik, Pelatihan Pengembangan Batik Berbasis Teknologi Informasi, UNIBA Surakarta

Rencana Kerja Disperindag Kabupaten Malang tahun 2018-2023

Rencana Pembangunan Jangka Menengah Daerah (RPJMD) Kabupaten Malang, 2018

Sahertian Juliuska, Entrepreneurship Perajin Batik Tulis Madura, Jurnal Entrepreurdan Entrepreneurship, Vol.5 No.2, September 2016

Teropong, Buletin Balitbang Provinsi Jawa Timur, Agustus 2017, ISSN 1412-8829 